\title{
Continuing Professional Education for Pre-service Teachers of Mental Arithmetic
}

\author{
Aigul R. Ganeeva*, Tatyana I. Anisimova \\ Department of Mathematics and Applied Informatics, Yelabuga Institute of the Kazan Federal University, Russia
}

Received May 19, 2020; Revised June 30, 2020; Accepted July 20, 2020

\begin{abstract}
Cite This Paper in the following Citation Styles
(a): [1] Aigul R. Ganeeva, Tatyana I. Anisimova , "Continuing Professional Education for Pre-service Teachers of Mental Arithmetic," Universal Journal of Educational Research, Vol. 8, No. 9, pp. 3989 - 3996, 2020. DOI: 10.13189/ujer.2020.080924.
\end{abstract}

(b): Aigul R. Ganeeva, Tatyana I. Anisimova (2020). Continuing Professional Education for Pre-service Teachers of Mental Arithmetic. Universal Journal of Educational Research, 8(9), 3989 - 3996. DOI: 10.13189/ujer.2020.080924.

Copyright $\subseteq 2020$ by authors, all rights reserved. Authors agree that this article remains permanently open access under the terms of the Creative Commons Attribution License 4.0 International License

\begin{abstract}
The intellectual development of preschoolers and primary school children is facilitated by mental arithmetic training using a system of quick oral math on an abacus. A continuing professional development program must prepare pre-service teachers to use innovative teaching methods for quick oral math during classroom and extracurricular activities. The purpose of the study is to determine the effectiveness of a continuing professional education program that prepares pre-service teachers to instruct in mental arithmetic. We developed and implemented the "Mental Arithmetic for Educators" program organized into five thematic blocks. The qualitative exploratory study (2017-2019) involved 25 participants majoring in teacher education, who did a questionnaire before and after completing the program and underwent praxis. To assess the effectiveness of the program, we analyzed the results of their questionnaires and praxis reports describing the implementation of innovative teaching methods. The results of the questionnaire show a rise in the level of the participants' ability to use innovative teaching methods during classroom and extracurricular activities, which the analyzed praxis reports proved. The findings demonstrate that after completing the program the pre-service teachers successfully introduced innovative teaching methods for mental arithmetic and contributed to increasing children's reaction times and ability to concentrate, that is boosted children's intellectual development. Such programs should be incorporated into the continuing education system of higher education institutions, which is novel in the international theory and methodology of preparing
\end{abstract}

pre-service and in-service teachers to instruct in mental arithmetic.

Keywords Intellectual Development, Innovative Teaching Methods, Mental Arithmetic, Continuing Professional Education Program, Pre-service Teachers

\section{Introduction}

During their higher education training, pre-service teachers prepare to implement pedagogical activities. Their mastering of innovative teaching methods contributes to the successful implementation of pedagogical activities in preschool and primary general education and, accordingly, the provision of quality educational services in accordance with children's needs. Their intellectual development is the value of education (Lewis, Watson, \& Schaps, 2013) and represents "both the process and degree of cognitive and mental activity of a developing personality in its various manifestations: cognitive processes, knowledge, skills, abilities, reasoning, talent, etc.” (Dzhioeva, 2015, p. 75).

Activities aimed at developing intellectual abilities and skills increase the level of intellectual development in preschoolers and primary school children, which eventually manifests as learning outcomes. Such activities include developing trainings that emphasize realizing children's potential and actively working to stimulate intellectual development (van Oers, B., 2012). In this regard, children's intellectual development is facilitated by 
using active learning simulation games both during classroom and extracurricular activities. Didactic games are widely used in this regard (de Freitas, 2018), which are aimed at enriching the cognitive, motivational, emotional-volitional and social spheres of the individual (Ge \& Ifenthaler, 2018).

It is important to consider the age-related peculiarities of children of preschool and primary school age, including those with special education needs, for the purpose of their intellectual development. These students will benefit from didactic games aimed at developing logical and analytical thinking (analysis, comparison, classification, generalization, creativity, as well as perception, memory, attention and imagination), visual-effective cognition, spatial imagination, combinatory and design abilities. For example, chess, puzzles, and logical computer games strengthen memory and concentration, develop the ability to compete, and offer satisfaction from gaining levels. Thus, successfully utilizing these games will contribute to children's intellectual development, in particular, the improvement of their cognitive and mental activities (Chen, Wang, \& Wang, 2011).

Mental arithmetic also contributes to achieving the same results in preschoolers and primary school children. It is built on teaching quick and accurate oral math (Barner et al., 2016) using a variety of techniques. Mental arithmetic is associated with the development of memory, attention, imagination, logic, ingenuity, reaction speed, non-standard thinking, interhemispheric interaction, and self-confidence in learners (Handley, 2014; Ganeeva \& Bekbulatova, 2017; Tsarev \& Tsareva, 2018). Interest in this type of oral math has increased recently as a result of a noted decrease in learners' ability to concentrate and be cognitively disciplined at this age of rapid development of information and communication technologies (Dobritsa et al., 2019).

The appearance in China more than five thousand years ago of a blackboard (suanpan) with special markings and sand divided into lines is considered to be the birth of teaching methods for quick oral math. These tools were used for addition, subtraction, multiplication, division, and for calculating fractions and square roots. Later, similar devices for arithmetic calculations appeared in Egypt, Ancient Greece and Ancient Rome. They were more like modern calculating methods in which the math was done on a board with stones or bone pieces instead of sand (Bagautdinov \& Ganiev, 2017).

Despite the fact that such tools were invented in China, they received more notice in Japan, where they were modernized and received the name "abacus" ("soroban" from the Japanese for "computing board"). These tools became popular in Japan in the 17th century when they were thoroughly studied by mathematicians. Their work improved the methods and techniques of making practical calculations on the abacus (Bagautdinov \& Ganiev, 2017).

The abacus has horizontal scores, "rectangular in shape with vertical spokes (13 or more, always an odd number) that hold pieces of bone. The spokes are divided by a longitudinal bar so that the top of each row has one bone, and the bottom has four" (Chernysheva, 2018, p. 127). To carry out mental arithmetic operations, learners are first taught to count by moving the bones in the scores with two hands. Then they mentally represent the abacus and visualize the numbers as bones in their mind (Frank \& Barner, 2012; Maulesheva \& Syrlanova, 2017). The visualization is also accompanied by actions that mimic moving the bones on the abacus (Brooks et al., 2018).

Oral math contributes to the effective development of mathematical skills in children in a playful way (Ku et al., 2014). Such skills include solving basic arithmetic problems (addition, subtraction, multiplication, and division) without the use of writing (Rathgeb-Schnierer \& Green, 2019). Oral math using mental arithmetic should be taught no earlier than at the age of four to six years old. That is when a child has learned their numbers from at least one to ten, which will allow them to get acquainted with their location on the instrument and perform basic operations. A person's brain undergoes its most intense development between four and 12 years old, and basic skills should be acquired precisely in that period (Malsan, 2017).

The earliest international studies of mental arithmetic using an abacus took place in the 1980s. A study by Japanese researchers G. Hatano and K. Osawa (1983) showed that being able to quickly perform mental calculations helps one better remember numbers. The American researcher J. W. Stigler described his observations of the effective quick mental math of 11-year-old Chinese children who used the abacus (Stigler, 1984). Researchers from Japan studied abacus proficiency and the responsiveness of their subjects to completing visual, spatial and verbal memory tasks (Hatano, Amaiwa, \& Shimizu, 1987).

Modern studies confirm that long-term training in quick mental arithmetic on the abacus has a positive effect on brain activity, and also improves functional integration in children. Researchers from Zhejiang University (Hangzhou, China) argue that visual thinking can reduce reaction time to tasks, which increases responsiveness and one's ability to concentrate. Improving the functional connection between the frontal and parietal regions of the brain allows students to more efficiently process tasks ( $\mathrm{Li}$ et al., 2013). Researchers at Stanford University (Stanford, USA) M. C. Frank and D. Barner (2012) concluded that mental calculations are more based on visual experience, in particular on the ability to represent multiple groups of objects along with creating visual representations.

Thus, scientists argue for the effectiveness of teaching children mental arithmetic, based on a quick oral math system using mathematical calculations on an abacus. The effectiveness can be achieved if the teacher knows the basics of mental arithmetic and the primary teaching methods, taking into account different hand arrangements 
when using an abacus, as well as learners' age and stage in the learning process. These peculiarities should be included in the curriculum of a continuing professional education program aimed at teaching mental arithmetic methodologies.

Instructing pre-service teachers in mental arithmetic is an interesting strategy because it does fulfill pedagogical activity requirements for engaging with innovative teaching methods during classroom and extracurricular activities. In this way, pre-service teachers will be able to implement strategies for teaching quick oral math using simulation games then as well. This will support active learning, which boosts children's intellectual development.

At the moment, training for teaching mental arithmetic is only available in the continuing professional education system. Undergraduate programs do not involve mastering this methodology. Existing programs for continuing professional education are focused on in-service teachers but do not target pre-service teachers. In this regard, the teacher training curriculum in the continuing professional education system should be reviewed.

Our research hypothesis can be stated as follows: if you develop and test a program in the continuing professional education system that involves teaching pre-service teachers how to instruct in mental arithmetic, they will be able to successfully introduce innovative teaching methods for quick oral math during classroom and extracurricular activities.

The purpose of the study is to determine the effectiveness of a continuing professional education program that prepares pre-service teachers to instruct in mental arithmetic.

\section{Methodology}

In order to prepare pre-service teachers to instruct in mental arithmetic, we developed a continuing professional education program called "Mental Arithmetic for Teachers" based on the modeling method. The title of the program was also its purpose, with planned learning outcomes (to know, have, and control) organized into thematic blocks.

The purpose of the "Mental Arithmetic for Teachers" continuing professional education program is to train teachers to plan and implement mental arithmetic learning during classroom and extracurricular activities in accordance with children's age and individual characteristics.

After completing this program, the teacher should know:

- the content and organizational principles of a mental arithmetic program;

- $\quad$ the methodology for teaching mental arithmetic;

- $\quad$ peculiarities of teaching mental arithmetic in various age groups, including learners with special needs;

- modern methods of monitoring and assessing learning outcomes.
They should be able to:

- develop mental arithmetic problems, which stimulates children's intellectual development during classroom and extracurricular activities;

- $\quad$ perform calculations on an abacus;

- collect, organize, select and adapt information to the lesson;

- $\quad$ use computer tools (simulators);

- develop and implement a lesson plan on mental arithmetic;

- develop programs on mental arithmetic in accordance with children's age and individual needs;

- evaluate and analyze learning outcomes and adjust the learning process if necessary;

- $\quad$ reflect on their teaching activities.

The content of the continuing professional education program was organized into the following thematic blocks:

1. Introduction to Mental Arithmetic

2. Basic Combinations and Formulas of Addition and Subtraction

3. The Methodological Specifics of Mental Math

4. Age-related Peculiarities of Teaching Mental Arithmetic

5. Implementation of Mental Arithmetic Technology in Classroom and Extracurricular Activities

The program involves combining classroom studies and independent work, which incorporates the learnt material into the actual practice of solving problems associated with teaching mental arithmetic. The program consolidates theoretical knowledge through a system of practical exercises, seminars and laboratory work. Group and individual advising is provided at the request of students. During full-time classes, students receive teaching materials and recommendations for teaching mental arithmetic.

The first block "Introduction to Mental Arithmetic" familiarizes students with the history of mental arithmetic, the abacus, and different hand arrangements when using an abacus. Students learn to count on an abacus using simple addition and subtraction with single-digit, double-digit and triple-digit numbers.

In the second block "Basic Combinations and Formulas of Addition and Subtraction," the main concepts of "brothers" and "friends" are taught. Students get acquainted with basic combinations and formulas for addition and subtraction:

1. Adding numbers using "help brother $\mathrm{HB}$ ” formulas:

$+1=+5-4,+2=+5-3,+3=+5-2,+4=+5-1$.

2. Subtracting numbers using "help brother HB" formulas:

$-1=-5+4,-2=-5+3,-3=-5+2,-4=-5+1$.

3. Adding numbers using "help friend HF” formulas: 
$+9=+10-1,+8=+10-2,+7=+10-3,+6=+10-4$,

$+5=+10-5,+4=+10-6,+3=+10-7,+2=+10-8$,

$+1=+10-9$.

4. Subtracting numbers using "help friend HF" formulas:

$-9=-10+1,-8=-10+2,-7=-10+3,-6=-10+4$,

$-5=-10+5,-4=-10+6,-3=-10+7,-2=-10+8$,

$-1=-10+9$.

5. Adding numbers using the combined "Mix formula MF”:

$+6=+11-5,+7=+12-5,+8=+13-5,+9=+14-5$.

6. Subtracting numbers using the combined "Mix formula MF":

$-6=-11+5,-7=-12+5,-8=-13+5,-9=-14+5$.

The second block teaches students how to perform simple exercises to master the basic formulas. The third block "The Methodological Specifics of Mental Math" explores the practice of mental math, contains recommendations for switching to mental math using mental maps, and addresses specifics of teaching children quick oral math, with age-related characteristics considered. In this block, the material is divided for working with preschoolers (4-6 years old), primary school students (7-9 years old), and teenagers (10-14 years old). Accordingly, the age-related peculiarities of teaching mental arithmetic are covered in the fourth block. The fifth block describes opportunities to implement mental arithmetic technology to teach children during classroom and extracurricular activities.

The continuing professional education program was implemented at the Yelabuga Institute of Kazan Federal University (Yelabuga, Russia) as the qualitative exploratory study. Over 300 students have been trained under this program since 2017. It is mainly taken by in-service teachers of mathematics and elementary grades receiving higher education in Teacher Education. The training takes place over a week as groups are recruited and consists of 36 credit hours total (classroom studies - 18 hours, independent work - 18 hours). After completing the program, students do an exam testing their ability to solve example problems on an abacus. They must use all the formulas correctly to become trainers of mental arithmetic.

The "Mental Arithmetic for Teachers" program was implemented between 2017 and 2019. There were involved students from one academic group enrolled in the full-time undergraduate program 44.03.05 Teacher Education (double majors: mathematics and physics). 25 students from one academic group participated in the program, so they learnt about innovative methods for teaching mental arithmetic.

The participants did one questionnaire before implementing the program (when they were fourth-years students in the 2017-2018 academic year) and after it (fifth-year students in 2018-2019). The questionnaire consisted of statements, or questions, relevant to the program's learning outcomes:

1. Using interactive teaching methods during classroom activities.

2. Using interactive teaching methods during extracurricular activities.

3. Using techniques to motivate children.

4. Using tools to test and assess children's learning outcomes.

5. Readiness to implement a student-centered approach to teaching children.

6. Ability to improve the teaching process.

7. Ability to self-assess your learning activity.

8. Using techniques of quick oral math.

9. Ability to implement methods of quick oral math in classroom and extracurricular activities in mathematics.

10. Ability to develop and adapt programs of extracurricular activities in mathematics in accordance with children's age.

The survey participants were to rate their learning outcomes, that is, the knowledge about innovative teaching methods to organize classroom and extracurricular activities which boost children's intellectual development. According to the rating, 10 could be marked as the highest point, while 0 - the lowest one; the points could be identical to different learning outcomes. The total points were calculated as the arithmetic mean value, which allowed analyzing the effectiveness of the "Mental Arithmetic for Teachers" program.

After that, the participants underwent praxis where they intended to implement learning outcomes during classroom and extracurricular activities. Praxis 1 took place from February 08, 2018 to March 21, 2018 for fourth-year students; praxis 2 - from November 15, 2018 to December 28, 2018 for fifth-year students. As regards extracurricular activities, they participated in educational projects for different age groups supervised by teachers. Such educational projects included "IntelLeto" and "KFUmniki" as well as the courses "Mental Arithmetic" and "Geometry," the "RoboSTARt.KIDS" school of robotics and "Children's University".

The reports of praxis 1 and praxis 2 were analyzed to determine the effectiveness of the program. They included notes and photographs of classroom and extracurricular activities, which were analyzed for the inclusion of innovative teaching methods in the activities. The methods contributed to boosting children's intellectual development and mastering the basics of quick oral math in particular.

The criteria for assessing the notes and photographs were as follows:

1. Ability to implement methods of quick oral math in classroom and extracurricular activities in mathematics. 
2. Ability to develop and adapt programs of extracurricular activities in mathematics in accordance with children's age.

3. Ability to employ visual aids in teaching quick oral math to children.

Each criterion could be assessed from 0 to 2 points. 2 points meant a high level of the ability assessed (the participants showed the ability to the full extent), 1 point average (they did not exhibit it fully), 0 - low (they did not demonstrate the ability).

As a result, the study determined the effectiveness of the "Mental Arithmetic for Teachers" program.

\section{Results}

The results of the survey participants rating the statements in the questionnaire before and after completing the "Mental Arithmetic for Teachers" program are found in Figure 1. It illustrates the average mean value for each question asked, that is for each statement, in questionnaires 1 and 2.

The results demonstrate a rise in the level of the participants' ability to use innovative teaching methods during classroom and extracurricular activities. The increase is evident in questions 8,9 , and 10 .

The details can be observed in Figure 2, which illustrates the rating for question 8 . Most participants used techniques of quick oral math on an average or low level before completing the continuing professional program as they did not consider such techniques effective enough. These results contrast with those after completing the program since the techniques contribute to children's intellectual development and increase their self-esteem.

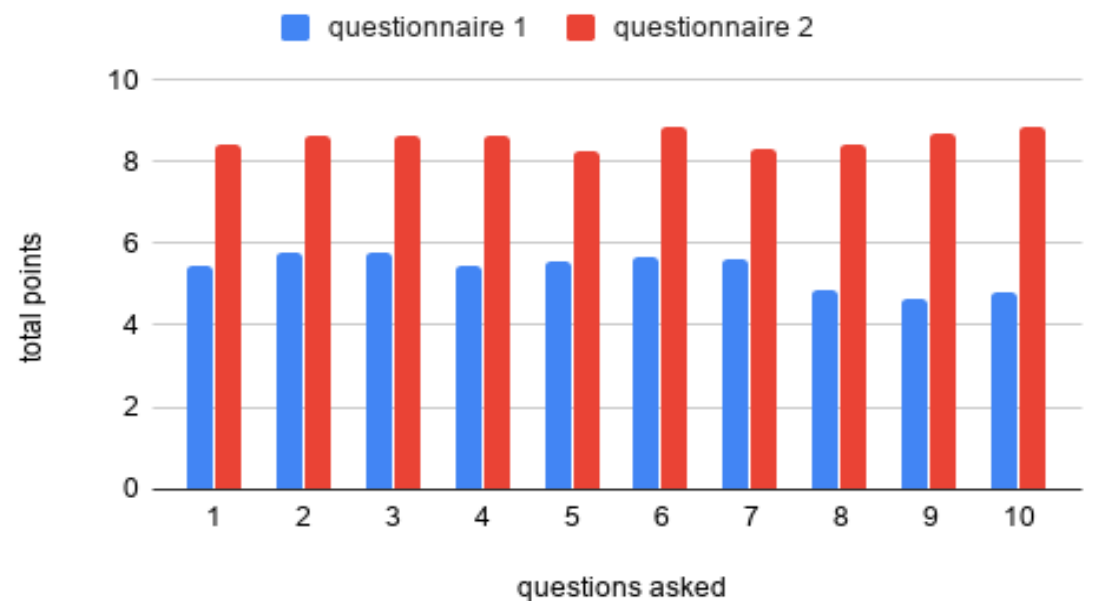

Figure 1. Results of questionnaires 1, 2

questionnaire $1 \square$ questionnaire 2

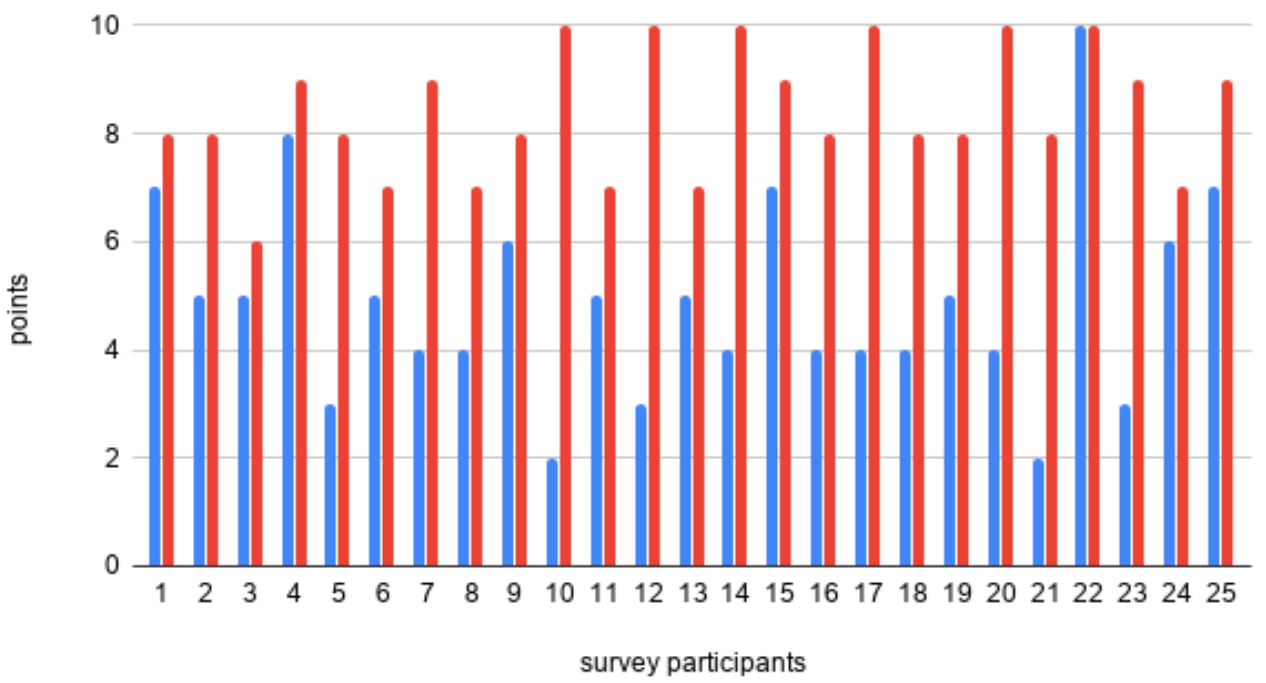

Figure 2. Results of question 8 in questionnaires 1, 2 


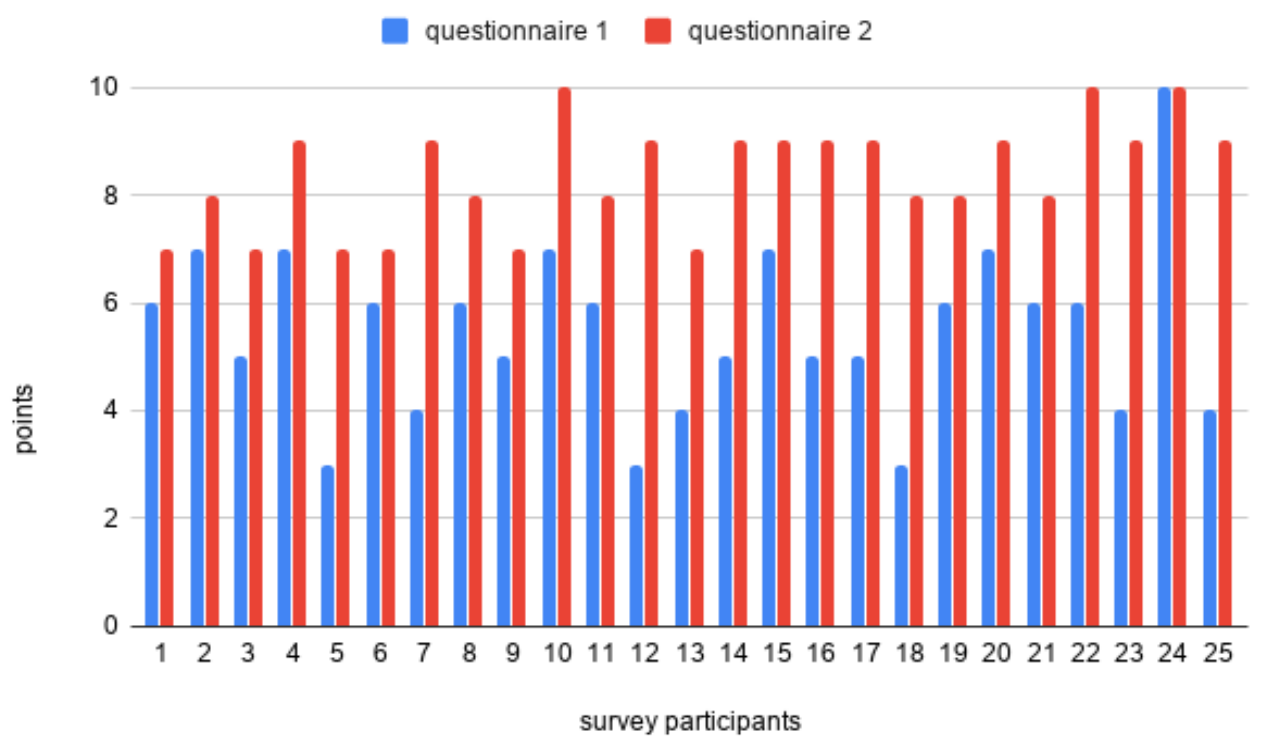

Figure 3. Results of question 1 in questionnaires 1,2

The dramatic increase in the results can be noted for question 1 (Figure 3). In the academic group, there are students whose level of using interactive teaching methods during classroom activities is high enough. Their interest in performing mental arithmetic effectively is associated with their right choice of the major.

Afterwards, the participants underwent praxis and submitted reports. All the reports were analyzed for the use of innovative teaching methods during classroom and extracurricular activities. Analysis of these activities showed that, in praxis, the participants began to use more innovative methods for teaching mental arithmetic. For example, in physical education sessions, students used tasks and games for interhemispheric interaction, as well as interesting flash mobs aimed at developing and changing children's activities.

A study of the activities reflected in the praxis reports indicates that participants presented a standard set of extracurricular activities including "February 23rd", "Mother's Day", "Valentine's Day", "Mathematical Kaleidoscope", "What? Where? When?" On the other hand, the reports also included creative extracurricular activities with students such as "Rubik's Cube Competition", "World of Puzzles", "Secrets of Mental Arithmetic", "Intellectual Leader", etc.

Accordingly, the "Mental Arithmetic for Teachers" program is proven to be effective among students undergoing training in Teacher Education.

\section{Interpretation of Study Results}

The study confirmed our hypothesis. In particular, during praxis, pre-service teachers successfully introduced innovative teaching methods for quick oral math. This was made possible thanks to training in methodologies for teaching mental arithmetic under a continuing professional education program which we had developed and tested. The participants displayed great interest in mastering new methods of oral math by themselves and learning how to teach them to children. They gladly participated in mental arithmetic instruction, thereby contributing to increasing children's reaction times and their ability to concentrate.

The content of the "Mental Arithmetic for Teachers" continuing professional education program reflects the specifics of children's intellectual development in accordance with their age, and also helps teachers master innovative methods for instructing in mental arithmetic. The testing of this program shows that it prepares teachers to introduce innovative teaching methods for mental arithmetic in children's classroom and extracurricular activities.

The results of the questionnaire indicate that the participants' level to implement interactive teaching methods has increased after completing the "Mental Arithmetic for Teachers" program. This means that those who have completed the continuing professional program have greater theoretical knowledge of innovative teaching methods for mental arithmetic. The results also indicate enthusiasm for using simulation games for active learning during classroom and extracurricular activities in order to boost children's intellectual development. Pre-service teachers' praxis reports confirm that training under this program has a positive effect on the development of their creative thinking. After praxis, some of the students remained in schools as assistant teachers (trainees) and helped organize and conduct classes.

After completing the "Mental Arithmetic for Teachers" continuing professional education program, pre-service teachers worked with children at the Children's University (classes were held once a month on Sundays), using their experience, creativity and rich methodological resources to develop student intelligence. Many pre-service teachers now work as instructors of mental arithmetic in the system 
of continuing education.

The findings confirm the importance of having a continuing professional education program on teaching mental arithmetic, which means that such programs should be incorporated into the continuing education system of higher education institutions. To conclude, the continuing professional education program that prepares pre-service teachers for teaching mental arithmetic in the context of developmental education is effective.

Only studies regarding teaching mental arithmetic to preschoolers and schoolchildren are present in international literature. For example, contemporary sources address neuroplasticity and indicate the effect of mental arithmetic on the functioning of visual-spatial short-term memory (Wang et al., 2019). Studies also confirm improvement in the cognitive and emotional abilities of students (Mokhberian \& Abedini, 2019).

However, international sources do not practically describe teaching methods for pre-service and in-service teachers of mental arithmetic. One noted study by L. P. Rosenblum, S. Hong and S. Amato (2013) described how 196 American and Canadian teachers were prepared to instruct in mental arithmetic on an adapted abacus (a Cranmer abacus) to visually impaired students. The study showed that teaching quick oral math was taught at higher education institutions, but methods and techniques varied.

This study is novel since there are not significant contributions to the international theory and methodology of preparing pre-service and in-service teachers to instruct in quick oral math using an abacus.

\section{Conclusions}

Innovative teaching methods are intended for children's intellectual development. Teaching mental arithmetic to learners of preschool and primary school age using simulation games for active learning is an example of an innovative teaching method that produces the intended effect. Not only do they develop their mathematical skills in a playful way but also their ability to concentrate on and develop their thinking.

Teaching quick oral math on an abacus is effective provided the teacher has mastered the basics of mental arithmetic and its teaching methods and understands children's age-related peculiarities. Those topics should make up the content of a continuing professional education program, which prepares pre-service teachers to instruct in mental arithmetic and, in turn, facilitate children's intellectual development.

We confirmed the effectiveness of the "Mental Arithmetic for Teachers" continuing professional education program during its implementation by pre-service teachers. The results of the questionnaire and praxis reports describe the implementation of innovative training methods; they testify to a pre-service teacher's competence with innovative teaching methods for performing mental arithmetic.

Thus, the development and testing of this program in the continuing professional education system allowed pre-service teachers to successfully introduce innovative teaching methods for quick oral math during praxis. This experience could be successfully implemented in the continuing education systems of different countries, and it should be taken into account when preparing pre-service teachers of various majors to instruct in mental arithmetic.

The researchers plan to pay more attention to working with learners with special education needs. Those needs will require adjustments to the content of a continuing professional education program for pre-service teachers. It will also be necessary to develop an adaptive program for learners of preschool and primary school age.

\section{REFERENCES}

[1] Bagautdinov, R. \& Ganiev, R. (2017). Mental'naya arifmetika. Znakomstvo (2nd ed.). Moscow: Trast.

[2] Barner, D., Alvarez, G., Sullivan, J., Brooks, N., Srinivasan, M., \& Frank, M. C. (2016). Learning mathematics in a visuospatial format: A randomized, controlled trial of mental abacus instruction. Child Development, 87(4), 1146-1158. Retrieved from doi: 10.1111/cdev.12515.

[3] Brooks, N. B., Barner, D., Frank, M., \& Goldin-Meadow, S. (2018). The role of gesture in supporting mental representations: The case of mental abacus arithmetic. Cognitive Science, 42(2), 554-575. Retrieved from doi: 10.1111/cogs.12527.

[4] Carev, S. A. \& Careva, R. S. (2018). K voprosu o pedagogicheskih resursah mental'noj arifmetiki V podgotovke detej $\mathrm{k}$ social'nomu vzaimodejstviyu. Sovremennye problemy nauki i obrazovaniya, № 4. [In Russ.] Retrieved from URL: https://science-education.ru/ru/article/view?id=27721

[5] Chen, M. S., Wang, T. C., \& Wang, C. N. (2011). Effect of mental abacus training on working memory of children. Journal of the Chinese Institute of Industrial Engineers, 28(6), 450-457. Retrieved from doi: 10.1080/10170669.2011.610365.

[6] Chernysheva, D. S. (2018). Osobennosti razvitiya tvorcheskogo potenciala lichnosti mladshih shkol'nikov sredstvami mental'noj arifmetiki // Voprosy pedagogiki. № 1, 127-132.

[7] De Freitas, S. (2018). Are games effective learning tools? A review of educational games. Educational Technology \& Society, 21(2), 74-84. Retrieved from https://www.j-ets.net/ ETS/journals/21_2/6.pdf.

[8] Dobrica, V. P., Dobrica, I. S., Loktionova, N. N. \& Atakishchev, O. G. (2019). Mental'naya arifmetika kak sredstvo podgotovki $\mathrm{k}$ kompressivnomu obucheniyu. Uchenye zapiski. Elektronnyj nauchnyj zhurnal Kurskogo gosudarstvennogo universiteta, № 1(49), 209-213. [In Russ.] Retrieved from URL: https://api-mag.kursksu.ru/media/pdf/ 054-029.pdf. 
[9] Dzhioeva, G. H. (2015). Intellektual'noe razvitie doshkol'nikov v processe podgotovki k shkole. Vektor nauki TGU. Seriya: Pedagogika, psihologiya, № 3(22), 74-78. [In Russ.] Retrieved from URL: http://edu.tltsu.ru/sites/sites_c ontent/site3456/html/media95856/14\%20Dzhioeva.pdf

[10] Frank, M. C. \& Barner, D. (2012). Representing exact number visually using mental abacus. Journal of Experimental Psychology: General, 141(1), 134-149. Retrieved from doi: 10.1037/a0024427.

[11] Ganeeva, A. R. \& Bekbulatova, A. R. (2017). Metody obucheniya ustnomu schetu. Fiziko-matematicheskoe obrazovanie: problemy i perspektivy: materialy II Vserossijskoj nauchno-prakticheskoj konferencii, posvyashchennoj godu N. I. Lobachevskogo. g. Elabuga, 79 dekabrya 2017 g., 22-25.

[12] Ge, X. \& Ifenthaler, D. (2018). Designing engaging educational games and assessing engagement in game-based learning. In Information Resources Management Association (Ed.), Gamification in Education: Breakthroughs in Research and Practice (pp. 1-19). Hershey PA, USA: IGI Global. Retrieved from doi: 10.4018/978-1-5225-5198-0.ch001.

[13] Handley, B. (2014). Speed Mathematics (3rd ed.). Camberwell, Vic.: John Wiley and Sons Australia.

[14] Hatano, G. \& Osawa, K. (1983). Digit memory of grand experts in abacus-derived mental calculation. Cognition, 15(1-3), 95-110. Retrieved from doi: 10.1016/0010-0277(83)90035-5.

[15] Hatano, G., Amaiwa, S., \& Shimizu, K. (1987). Formation of a mental abacus for computation and its use as a memory device for digits: A developmental study. Developmental Psychology, 23(6), 832-838. Retrieved from doi: 10.1037/0012-1649.23.6.832.

[16] Ku, O., Wu, D. H., Lao, A. C.-C., Wang, J.-H., \& Chan, T.-W. (2014). The effects of mini-games on students' confidence and performance in mental calculation. In $\mathrm{T}$. Supnithi, S. C. Kong, Y.-T. Wu, T. Kojiri, C.-C. Liu, H. Ogata, \& A. Kashihara (Eds.), 22nd International Conference on Computers in Education, ICCE 2014 (pp. 436-445). Nara, Japan: Asia-Pacific Society for Computers in Education.

[17] Lewis, C., Watson, M., \& Schaps, E. (2013). Recapturing education's full mission: Educating for social, ethical, and intellectual development. In C. M. Reigeluth (Ed.), Instructional-Design Theories and Models: A New Paradigm of Instructional Theory (pp. 511-536). NY, USA: Taylor and Francis. Retrieved from doi:

\section{$10.4324 / 9781410603784$.}

[18] Li, Y., Hu, Y., Zhao, M., Wang, Y., Huang, J., \& Chen, F. (2013). The neural pathway underlying a numerical working memory task in abacus-trained children and associated functional connectivity in the resting brain. Brain Research, 1539, 24-33. Retrieved from doi: 10.1016/j.brainres.2013.0 9.030 .

[19] Malsan, B. (2017). Mental'naya arifmetika: Dlya vsekh. Ekaterinburg: Izdatel'skie resheniya. [In Russ.]

[20] Maulesheva, A. \& Syrlanova, S. T. (2017). Rol' mental'noj arifmetiki v razvitii vnimaniya i myshleniya doshkol'nikov. Izvestiya instituta pedagogiki i psihologii obrazovaniya, № 1, 96-99. [In Russ.] Retrieved from URL: http://ippo.selfip.com:85/izvestia/wp-content/uploads/2017/ 05/N1-2017.pdf.

[21] Mokhberian, R. \& Abedini, E. (2019). Studying the effect of mental calculations training with abacus on the learners' cognitive and psychological-emotional characteristics (intelligent \& creative children institute). Journal of Social Sciences Research, 5(3), 733-737. Retrieved from doi: 10.32861/jssr.53.733.737.

[22] Rathgeb-Schnierer, E. \& Green, M. G. (2019). Developing flexibility in mental calculation. Educação and Realidade, 44(2), e87078, 1-17. Retrieved from doi: $10.1590 / 2175-623687078$.

[23] Rosenblum, L. P., Hong, S., \& Amato, S. (2013). The abacus: Teachers' preparations and beliefs about their abacus preservice preparation. Journal of Visual Impairment and Blindness, 107(4), 274-285. Retrieved from doi: 10.1177\%2F0145482X1310700404.

[24] Stigler, J. W. (1984). "Mental abacus": The effect of abacus training on Chinese children's mental calculation. Cognitive Psychology, 16(2), 145-176. Retrieved from doi: 10.1016/0010-0285(84)90006-9.

[25] Van Oers, B. (2012). Developmental education: Foundations of a play-based curriculum. In B. van Oers (Ed.), Developmental Education for Young Children: Concept, Practice and Implementation (pp. 13-25). Springer Netherlands. Retrieved from doi: 10.1007/978-94-007-4617 $-6 \_2$.

[26] Wang, C., Xu, T., Geng, F., Hu, Y., Wang, Y., Liu, H., \& Chen, F. (2019). Training on abacus-based mental calculation enhances visuospatial working memory in children. The Journal of Neuroscience: The Official Journal of the Society of Neuroscience, 39(33), 6439-6448. Retrieved from doi: 10.1523/JNEUROSCI.3195-18.2019. 